Александра Пауновић

Институт за књижевност

и уметност, Београд

e-mail: ale.paunovic@gmail.com
821.163.41.09-14 Андрић И.

https://doi.org/10.18485/ai_lik.2020.6.10.2

Оригинални научни рад

\title{
У ЛИРСКОМ ПРЕМЕРУ СНА И ЈАВЕ: „ШТА САҢАМ И ШТА МИ СЕ ДОГАЂА“ ИВЕ АНДРИЋА ${ }^{1}$
}

У раду се проматрају књижевнотеоријске, књижевнокритичке, сазнајно-интерпретативне могућности и домети феноменолошке методе у разумевању Андрићеве десетоделне песме „Шта сањам и шта ми се догађа“. Примењујући ингарденовску методологију и теоријске постулате задане студијама $O$ кюижевном gелу и О сазнағу књижевноі уметиничкої gела, али и њене одјеке, примену и ограничења унутар српске књижевнокритичке мисли (Зоран Константиновић, Драган Стојановић), интерпретираћемо текст Андрићевог лирског циклуса.

Кључне речи: Андрић, Ингарден, феноменолошка метода, лирика, филозофија књижевности, књижевна теорија, слој, опализација

1.

Сабрано лирско стваралаштво Иве Андрића први пут је постхумно објављено у оквиру Сабраних gела Иве Анgрића 1976. године (Београд: Просвета) чији су приређивачи Вера Стојић, Радован Вучковић, Мухарем Первић и Петар Џаџић. Обухвативши Андрићеву рану лирику, Ex Ponto, Немире, која за пишчева живота није имала поновљена издања, приређивачи су у издање уврстили и поезију објављивану у

1 Текст је настао као резултат ангажовања на пројекту Смена йое-

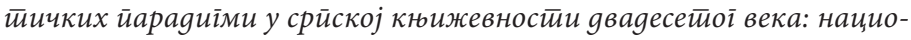

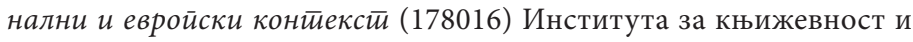
уметност (Београд), који финансира Министарство просвете, науке и технолошког развоја Републике Србије. 
периодици као и необјављену поезију из рукописне заосташтине, начинивши при томе неколике текстолошке недоследности према аутентичном тексту, које су донекле исправљене у издању из 1981. године. Како нам је предмет истраживања одређен Андрићевом песмом „Шта сањам и шта ми се догађа“, издвојићемо оне текстолошке проблеме које се непосредно тичу ње. Наиме, пре него започнемо тумачење морамо одредити сам предмет тумачења, прецизније речено, морамо јасно представити шта је оно што сматрамо да чини текст песме „Шта сањам и шта ми се догађа“, јер је услед специфичне генезе текста и историје његовог издавања и приређивања, основни текст непрецизно одређен.

У првоме издању из 1976. године „Шта сањам и шта ми се догађа“ штампана је као деветоделна песма, док је у проширеном и допуњеном издању из 1981. године издата као десетоделна песма. Ово друго издање садржи упутне „Белешке“ и „Напомене“ које откривају поступке приређивања Андрићеве лирике. О песми „Шта сањам и шта ми се догађа“ наведено је, поред списка бројева часописа у којима су појединачне песме излазиле (Мисао, Данас, Прейлеg) и:

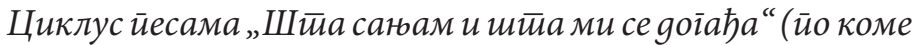
је иррво йосиххумно изяаюе лирике добило наслов), јеgна оg најамбиичознијих Андрићевих ӣесничких иелина, има десей иеввана и објављиван је у тири наврайа оg 1922. gо 1931. іолине.

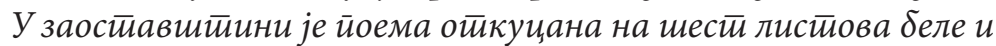

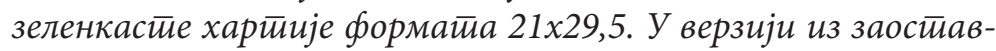
итиине има јеgна неgослеgности. Певане десейо, објавлено у

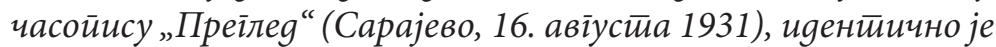
са седмим йеванем с йим ийо је сеgмо иеване дайо у језички нешйо нейрочишћеној верзији, йа су исиравке унесене руком

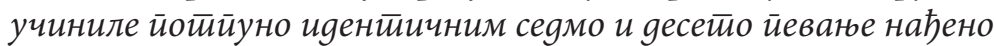
у заостиавийини. У йрвом йосиххумном издану ириређивачи су ӣреузели верзију из заостиавшитине и искључили јеgно оg

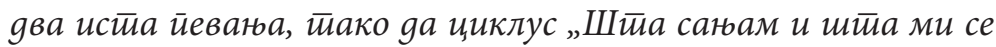
gоїађа“ има укуйно девей иевевьа.

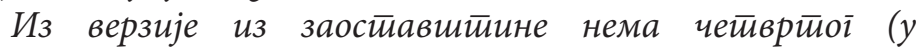
сйвари сеgмої) иеввана својевремено објавъеноі у часойису „Мисао“(1923): 
„На йуђем мору. Не йрайе мене

Сенка gоброї воћюака

Ни вишеіраяска стиаза, увек тижнна.

Блеgе блаїостови.

Тону gарови у данима и мору;

Гину ожиљици рана̂ и миловағьิ...

За увек!

А изнаg мене и неба и мора

Јеgино име, иить и знак и снаїа:

Жеђ моја бескрајна времена и свешиа."

Смайрајући gа је ова иесма омашком оиийла из вер-

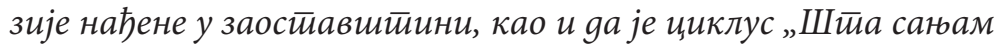
и шита ми се gоїађа" неgетива иелина у десей иевань, ирриређивачи уносе у ово издате изосииавлену иесму. Минималне исиравке махом словних ірешака унесене су иррема верзији из

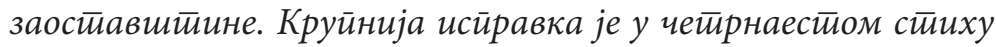
(одозіо) йеваюь I. Сйоји: „Да се йроктује јеgном модра сина изнаg ілаве“. Исирављено: „Да се йроктује јеgном модра ойна изная ілаве“.

Под насловом „Туђина“ и са белешком Рим, сейтем 1920, йосйоји у заостиавшитини йосебна иессма. Међуйим, она је инитеірисана у циклус „Шйа сағам и ийа ми се gоїађа“ као седмо иевване.

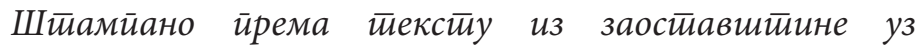
коришћете верзија из 1922, 1923. и 1931. iog. (1981: 303-304)

На основу наведеног дела текста „Напомена“ увиђамо да іррабички лик песме „Шта сањам и шта ми се догађа“" није отисак оригинала рукописа, већ је контаминација заоставштине и грађе објављиване у књижевној периодици, тј. коначни облик песме одредила је интервенција приређивача, а не закономерност затеченог стања у пишчевој заоставштини и/или књижевној периодици. Како се ради о тзв. популарном издању у самом тексту нису назначене јасне границе верзија из рукописа и из објављеног материјала, што отежава 'проходност' до аутентичног облика који је у 
битном слислу одређен ойвореношћу процесу настајања. Наиме, о лирском циклусу „Шта сањам и шта ми се догађа“ као и о Знаковима йopeg йyйa не може се говорити о завршеном, коначном облику у дословном смислу, јер је смрт прекинула писца у раду на њима. Бројне исправке које је писац уносио у дактилографисан рукопис, степен разлике између штампаних верзија у књижевној периодици, антологијама и рукописних верзија сведоче о континуираном пишчевом раду који налаже постављање питања конституисања

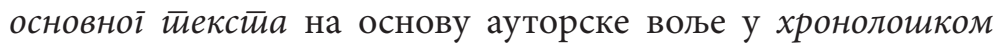
смислу. Примера ради, упоредићемо делове песме штампане у часописима (Мисао, Преілеg) и антологијама за пишчева живота и њихов рукопис. У Анйолоіији најновије тирике (1927) коју је приредио Сима Пандуровић на основу часописа Мисао Андрићева „Шта сањам и шта ми се догађа“ има четири ненасловљене целине: I [Ко ће знатии времену крај], II [Још касно у ноћи], III [На йуђем мору], IV [Заборављене млаgостии месеиа Јула] које ће се тим редоследом појавити и у антологијама Поезија Сарајева и Срйски йесниии између gва райа. Међутим, у дактилограму и у рукопису Андрићеве лирике и лирике у прози који се чувају у САНУ под сигнатуром IA 154 наведене целине су другачије нумерисане. Наиме, под наведеном сигнатуром налазе се четири песме везане

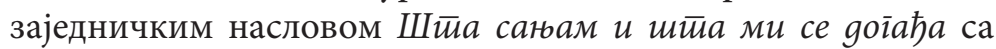
првим стиховима: Ко ће знатии времену крај (IV), Још касно y ноћи (V), Дани се іасе (VI), Неизрециву снаїу gају gуху и иеллу (VII). Ваља напоменути да песма која почиње стихом Још касно у ноћи има две строфе као и у Анйолоіији најновије тирике Симе Пандуровића и у Х књизи часописа Мисао (в. Андрић 1922: 1398-1399), док у антологијама Поезија Сарајева Хусеина Тамишчића и Срйски иееснии између gва

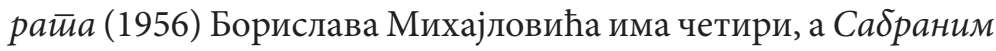
gелима састављена је из само једне строфе, што поставља задатак раздвајања приређивачких интервенција од ауторског рада на форми песме.

У временском интервалу од 1922. до 1931. године на страницама Мисли и Преілеgа Иво Андрић издаје десет песничких целина под заједничким насловом Шйа санам $u$ 
шита ми се gоїађа. Наиме, у Мисли издаје осам песама 1922. и 1923. године у X и XIII књизи, при чему се нумеризација песама не преноси из књиге у књигу. У X књизи штампане су песме са првим стиховима Буgим се врео, Танак месеи наg Луніарном, Иза йреgірађа, gалеко у редоследу I-III (Андрић 1922: 1248-1249), а у XIII књизи Ко ће знатии времену крај, Још касно у ноћи, Дани се іасе, На йуђем мору, Заборављене раgостии месеиа Јула у редоследу I-V (Андрић 1923: 13981399). Међутим, сарајевски Преілеg 1931. године издаје још

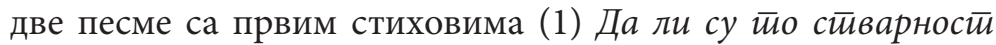
суние и облаци?, (2) Неизрециву снай gају gуху и иеллу (датиране 1921. године) као IX и Х део песме (видети Андрић 1931: 101-102), што имплицира обједињење појединачних песама у одређеном поретку, а чија се линија генезе донекле може реконструисати на основу рукописне грађе.

Несумњиво је, дакле, да је писац дорађивао стихове „Шта сањам и шта ми се догађа“, мењајући распоред песама, али са свешћу о њиховој уцеловљености у једну песничку творевину, те је пред нама дело са неокончаним стваралачким процесом, јер не можемо поуздано знати да ли је последња реч предата заоставштини. Појављивање и изручење ове Андрићеве песме пољу рецептивне свести, у феноменолошком смислу, морало би се одвијати и у йре-йростиору стабилних, фиксираних форми, на имагинативном хоризонту песничке (само)свести, која унутар себе, чува $\bar{u} р а \bar{\imath}$ настајања и грађења, где су poiesis i technée живо сучељени. У том смислу, намеће се питање којим се начином може промишљати и разумети ойворено, незавршено gело, може ли се говорити о онтолошкој равни насйајуће иесме, песме која то тек треба да постане у наступајућем тренутку последње пишчеве мисли/речи које нема и не може је више као такве бити? Но, овако постављена питања излазе из оквира основних услова која поставља Ингарден у промишљању књижевног дела, јер феноменолошко мишљење претпоставља чврстину облика/форме која се изручује чистој свести:

Бавићу се исктучиво завриеним книжевним делом. Као „завршено“ смаирам књижевно дело онда каgа су све 
реченице и йојеgиначне речи које се у ғему јављају јеgнозначно устиалене/уйврђене у смислу юихове звучностии, смисла и (узајамной) реgослеgа. [...] На тиај начин остиавльамо изван ірраница нашеі размайраға како саму фазу настианка

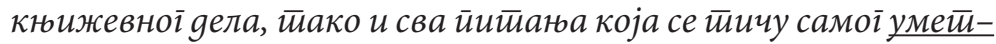
ничкої сииваралашйва. (2006: 35, истакао Р. И.)

Ингарден се чува нецеловитих текстова, не желећи да доспе у поље проматрања психологије стварања, остављајући по страни и питања филолошке и текстолошке корумпираности ауторског текста, јер би она угрозила говор о стабилности књижевног дела као щемайизоване творевине чији

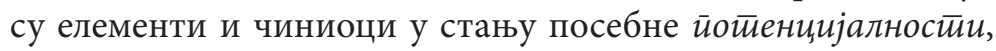
тј. нестабилност темеља уметиничких чиниоца одразила би се на произвољност изведених естиетиччких закономерности (видети Ингарден 2006: 332). Упитаност над настајућом песмом тражи могућност за критичко мишљење незавршеног, у смислу остајања унутар gо-краја-несирровеgеноі песничког мишљења. Другим речима, тражи књижевнокритичко и књижевнотеоријско мишљење текстовности недовршеног и/или недовршивог текста као једног од модуса постојања књижевноуметничког дела. Отварајући ова питања, дакако, запажамо да је Ингарденова примена феноменолошке методе постављена тако да не покрене овакву проблематику, избегавајући примере попут Процеса Франца Кафке. Међутим, за Процес као и за Газgа Млаgена Б. Станковића, Кюиіуу о Микеланђелу М. Црњанског или за Омерйашу Латиаса И. Андрића не може се рећи да су нецеловита књижевна дела у погледу поетичких и естетичких мерила. У чему лежи, дакле, смисао довршености/довршивости књижевног дела, ако се конституисање целине одвија и пре самога краја? На примеру дела које смо управо навели, запажамо да се довршеност и/или недовршивост формирала на простору йре саме довршености, пре оне одсудне последње речи која сигнализира рубно место књижевног уметничког остварења, тј. остварен крај и/или одсуствовање његове могућности присутни су већ начином започињања, кроз укупност дела - положени у његову ентелехију која се ослобађа 
у интерсубјективној позицији - у читању. Међутим, испитивања у овом смеру изискивала би једну (пост)фукоовску теорију дискурса, али и поетику читања која би могла да имплементира мишљење незавршених дискурса - њихов поредак, место и смисао спрам завршених, целовитих дискурзивних (и читалачких) форми.

2.

Оцртавајући неколике текстолошке недоумице и непознанице 2 у претходноме делу рада, истакли смо текстовне особине и условности ирриређеног̄ изgаға Андрићевог дела „Шта сањам и шта ми се догађа“. Услед непоузданости текста и контаминације верзија из Сабраних gела, ослонићемо се на верзију десетоделне песме публиковане на страницама часописа Мисао и Преїлеg за време пишчева живота, на њен іра-

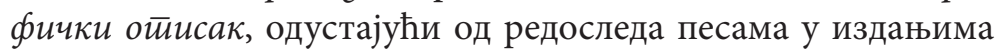
из 1976. и 1981. године. Редослед песама преузет из књижевне периодике је следећи: I [Буgим се врео], II [Танак месеи, наg Луніарном], III [Иза йреgірађа, gалеко] IV [Ко ће знайи времену крај] V [Још касно у ноћи], VI [Заборавльене раяосиии месеи, јула], VII [На йуђем мору; штампана само у издању из 1981. године], VIII [Дани се їасе], IX [Да ли су сйварносй суние и облаии], Х [Неизрециву снаіу gају gуху и йелу].

Описивање „суштинске анатомије“ књижевног дела, Р. Ингарден започиње уводном расправом да ли је књижевно дело идеалан или реалан предмет: „Одмах ћемо се уверити да у том „или-или“ не можемо добити никакво решење“, наглашава аутор, решавајући проблем начина постојања

2 Проблем са установљењем основноі йекстй лирских остварења (у стиху и прози) И. Андрића протеже се и на његово прво објављено дело. Наиме, Душан Иванић студијом „Ех Ponto Иве Андрића питања успостављања основног текста“ запажа да је прво посмртно издање из 1976. године издато у 'искривљеном лику' спрам аутентичног андрићевског текста, који је проузрокован непостојањем доследног односа према изворнику и контаминацијом верзија (више у Иванић 1980: 377-389). 
књижевног дела, његов eidos у целини студије, кроз подобно издвајање појединачних истовремених слојева, одбацујући претпоставку из које и настаје питање, а која унапред додељује књижевном делу „нешто што му је унапред страно“ (2006: 25-26). Хетерономни, неухватљиви ентитет „ни реално ни идеално“ Ингарден покушава да обухвати вршећи феноменолошку реgукиију, ${ }^{3}$ сужавајући обим иниеересноі йољь у иситраживануу.

На самом йочейку Кюижевног уметиничкой gела, дакле, аутор одређује шта не спада у књижевно дело, инсистирајући на чињеници да књижевно дело упућује на акйе свестии, који су његов основ, тј. извор његовог бића. Остављајући само оно што је за онтологију књижевног дела релевантно, Ингарден одстрањује све околности везане за постанак дела: биографију и животно искуство аутора, историјско-друштвене околности, ограђујући се и од могућих прототипова. На другој страни, читаочева својства, његови психичко-емоционални доживљаји такође су изван интересовања, премда је један део студије посвећен конкрейизацији. Међутим, како је конкретизација, тј. круг читаочевих активност уписан и задан кодом уметничког дела, не може се говорити о апсолутно ослобођеном приступу и релативизму рецепцијске

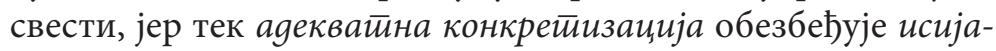
ваюе естетичких квалитета и њихову полифонију. Иако су феноменолошке претпоставке познате, овде ћемо навести оне релевантне како бисмо тумачење оријентисали према њима, са посебним интересом у тумачењу слојева и феномена опализације:

3 Драган Стојановић бележи запажање Манона Морен-Гризебаха о природи примењене феноменолошке редукције на књижевно дело, остављајући по страни захтев Зорана Константиновића да се Хусерлово виђење може тумачити, у овом контексту, и нешто друкчије (видети Константиновић 1969: 58): „Манон Марен-Гризебах тачно примећује [...] да се редукција, која се врши на објективном и на субјективном полу, у случају књижевног дела на објективном полу врши с обзиром на дело, а на субјективном с обзиром на читаоца. Просто речено, ако желимо да проучимо књижевно дело, онда се не сме узимати ништа друго осим дело само. Тек такав поступак обезбеђује, у складу с основним мотивима феноменологије, успех у тражењу истине“. 
1. Књижевно уметничко дело је интенционална творевина - полазиште за све остале ставове

2. Интенционалност књижевног уметиничког̄ дела је у нарочитој вези са такозваним quasi-модификацијом која постоји у њему

3. Књижевно уметничко дело је вишеслојна ${ }^{4}$ уметничка творевина

4. Књижевно уметничко дело је у стању да каткад произведе тзв. метафизичке квалитете

5. Постоји разлика између књижевног уметничког дела и естетског предмета, између уметничких и естетских вредности (Стојановић: 47-48).

Како је у тумачењу појединачног књижевног дела тешко извести прецизан аналитички рез међу слојевима, јер они превасходно постоје у динамици међуодноса и прожимања, описаћемо слојевитост Андрићеве песме као вид испољавања њене йолифоније есиетиских (и метафизичких) ква-

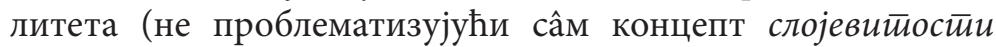
књижевноуметничког дела). Слојеви се разликују по матиеријалу и улози коју врше унутар јединствене целине књижевног текста, вели Ингарден, али међу њима ипак један слој „представља структурни костур читавог дела. То је слој значењских целина. Он се са своје стране дотиче свих осталих слојева, а неке од њих сам по себи тако означава да у њему имају основу своје егзистенције и да су по свом садржају зависни од његових особености. Као елементи књижевног дела ови слојеви се не могу одвојити од тог централног слоја.“ (2006: 43, курзив Р. И.). Започнимо, дакле, детекцијом

4 Р. Ингарден дефинише четири основна слоја: 1) слој вербалних звучности и језичке звучне творевине које се на њих надограђују, 2) слој значењских јединица и целине различитих нивоа, 3) слој разноврсних шематизованих аспеката и токова или аспекатских низова, 4) слој представљених предмета у делу и њихових судбина (2006: 44). Касније, у Х поглављу студије О кюижевном gелу, испитујући типове и домете функција четвртог слоја, издваја метиабизичке квалит̄етеие (в. Ингарден 2006: 263-269). 
централног слоја, ${ }^{5}$ иако он нема главну улогу у естетској аперцепцији књижевног уметничког дела.

Проматрајући значеюске јеgинице / иелине дела „Шта сањам и шта ми се догађа“, запажамо неколико сталних елемената око којих гравитира песничка имагинација или сағыреюе, како би то рекао Г. Башлар. Поље песничког искуства,

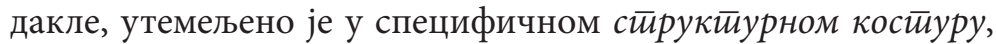
који ћемо табеларно, према кључним речима, представити. Појам кључних речи користимо условно како бисмо указали на постојање лајтмотивског језгра и/или обликотворних чиниоца читалачке мапе:

\begin{tabular}{|c|c|c|c|c|}
\hline $\begin{array}{c}\mathbf{I} \\
{[\text { byguм ce }} \\
\text { speo.] }\end{array}$ & $\begin{array}{c}\text { II } \\
{[\text { Танак }} \\
\text { месеи...] }\end{array}$ & $\begin{array}{c}\text { III } \\
{[\text { Иза }} \\
\bar{u} p e g i \bar{p} a ђ a . . .]\end{array}$ & 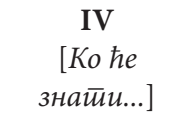 & $\begin{array}{c}\mathbf{V} \\
{[\text { Jош касно...] }}\end{array}$ \\
\hline $\begin{array}{c}\text { сjај } \\
\text { тишина }\end{array}$ & жеља & $\begin{array}{l}\text { звук } \\
\text { (чудо) }\end{array}$ & $\mathrm{caH}$ & $\mathrm{caH}$ \\
\hline $\begin{array}{c}\text { VI } \\
\text { [Дани се } \\
\text { iace.] }\end{array}$ & $\begin{array}{c}\text { VII } \\
{[\text { Ha } \overline{\bar{u} y ђ е м}} \\
\text { мору.] }\end{array}$ & $\begin{array}{c}\text { VIII } \\
{[\text { [заборавльене...] }}\end{array}$ & 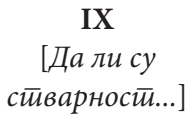 & $\begin{array}{c}\mathbf{X} \\
{[\text { Неизрециву }} \\
\text { снаіуу...] }\end{array}$ \\
\hline $\mathrm{caH}$ & $\begin{array}{c}\text { жеђ) } \\
\text { (жеља) }\end{array}$ & жеља & $\begin{array}{c}\text { стварносно: } \\
\text { снови }\end{array}$ & $\begin{array}{c}\text { сјај } \\
\text { тишина }\end{array}$ \\
\hline
\end{tabular}

„Шта сањам и шта ми се догађа“ јесте својеврсна десетоделна лирска варијација мотива сна и јаве/догађаја кроз њихово гранање на мотиве жеље, звука, сјаја, тишине. Преливање ових

5 Р. Ингарден упозорава да не треба мешати значењске целине језичких творевина са ияеалним смислом йојмова, што представља још једно од упоришних места полемике са Хусерлом. Наиме, Р. Ингарден не налази могућност за идентификацију целокупног садржаја идеалног појма унутар појединачне речи или исказа, усмерених ка њему, јер идеални појам представља ӣотенцијални састиавни gео значења оgређене речи. Идеални појам може бити актуализован, и то не у целини, али ако дође то тога „значење подлеже одређеној промени“, промени која се „једино заснива на обоїћену постојећег састава његовог материјалног садржаја.“ (2006: 103-104) Пажљиво спроводећи идеју потенцијалне енергије идеалних појмова у реалним исказима, Ингарден, заправо ствара тло на коме ће извести идеју метиафизичких квалитиети а као присуствовања сувишка зна-

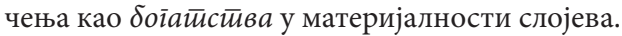


тематско-мотивских сфера из једне у другу целину, омеђено је првом и последњом песмом у којој су ойализацијом мотива тишине и мотива сјаја постављене две граничне тачке простора песничког ја. Осцилирањем од сна до будно догађајног/живљеног, мењањем позиције лирске (само)свести, песмин простор постаје двоструко опточен: интимом лирског субјекта и простором $\delta$ ћ $а$ - онога што јесйе, задобијајући елементе поунутрашњене драме постојање. Ова драма постојања као драма ношења идентитета, опсесивна тема Андрићевог стварања резултат је, феноменолошким идиомом казано, свеобухватног процеса инйендирања и формирања корелайа, који захвата све слојеве књижевноуметничког дела. Наиме, Роман Ингарден настојећи да опише међусобну повезаност тзв. „света дела“ и појединачних речи, исказа, дефинише појам инйеницонално$c \bar{u} u$, који је у феноменологији кључни појам. Хусерлова идеја усмереностич на, касније код Сартра модификована у појам

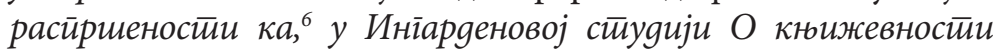
постаје темељна претпоставка онтолошке бити књижевног дела. Сазнавање вишеслојне структуре књижевног дела пропраћено је брижљивим настојањем да се унутар сваког појединачног слоја изведу функиије чисто интенционалног карактера којима се успоставља целина књижевне уметничке творевине у међусобној зависности и здружености слојева:

\section{[...] речи здружене у (исказну) реченицу инйенди-} рају, вршећи своју вербално-номиналну функиију развијана

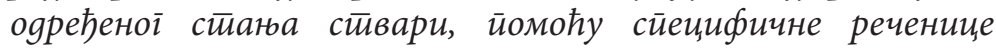

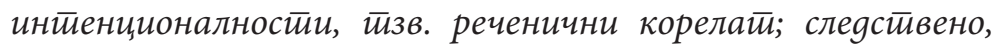
скуйови речении, у у којима се констиитиуишу јединиие смисла

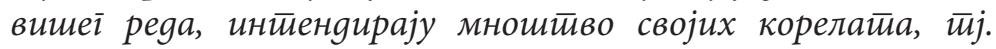

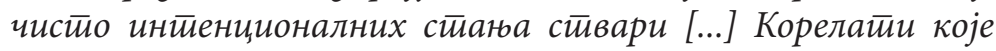

6 Жан Пол-Сартр у студији О кюижевносӣи и йисиима закључује да феноменологија открива једну свест која се расйрскава ка (1962: 253), постулирајућу нужну везу свести са светом како би се свест остварила као свест. Остваривање свести као свести унутар феноменолошког мишљења, међутим, не подразумева метафизичку систематизацију ни испитивање a priori услова сазнања, у кантовском

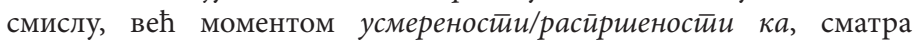

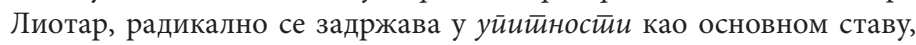
који води суштинској недовршености (1980: 12-13). 


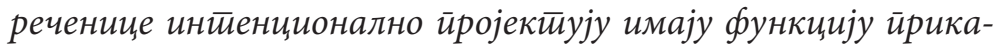
зиваюа „свейа“(Стојановић 1976: 54-55).

Како нам је у средишту структуре лирског циклуса питање саставности садржаја сна $u$ јаве, оно догађајно $u$ сневано уписује се унутар круга искуства субјективитета лирског ја. Индикативно је запазити речитост и једноставност наслова који комуницира са свих десет целина, тј. са свим варијантама значењског језгра, одређујући, у битном смислу, однос лирске самосвести и предмет певања. Наслов као почетно, истакнуто место, својим значењским капацитетом распростире се целокупним текстом на нивоу садржине употребом етиччкоі gaйива личне заменица ја чиме је назначен ентитет тицања, тј. информативни фокус пада на тицајући однос између лирског гласа и садржаја песничког говора. Управо зарад ове снажне текстовности наслова као надређене, окупљајуће сфере, о овој Андрићевој лирској творевини можемо говорити као о тирском циклусу, ${ }^{7}$ садржај наслова насводњава циклотворне везе између појединих песама. Она допунска, $\bar{ш} р а н с$ и мети $а$ значења која настају у односу целине и дела, циклуса и појединачне песме, која не губи самосталност, ${ }^{8}$ али саучествује у креирању јединица

7 О теорији лирског циклуса и цикличности погледати студије: Елени Стерјопулу Апостолос, Поетиика тирскоі изиклуса на матиеријалу руске йоезије с краја ХІХ и йочейком XX века, прев, Добрило Аранитовић, Београд: Народна књига, 2003; Светлана Шеатовић-Димитријевић,

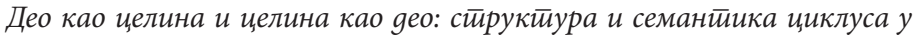
йоезији Васка Поиее и Ивана В. Лалића, Београд: Чигоја штампа, 2012; Ичин Корнелија, Лирски циклус у словенским књижевностима, Зборник Майице срйске за слависӣику, књ. 52 (1997), 347-349.

8 Е. А. Стерјопулу бележи став И. В. Фоменка из есеја Лирски изилус као

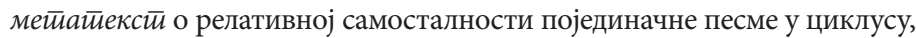
јер се иначе „не би могло говорити о лирском циклусу, већ о нефабулативној лирској поеми“ (2003: 40-41). Иако приређивачи о Андрићевом стиховном остварењу „Шта сањам и шта ми се догађа“ истовремено говоре као о поеми и циклусу, налазимо да кохезивне везе међу песмама у поновљивости појединих значењских јединица, оваплоћују један десетоделни лирски циклус, уоквирен ойалношћу мотива сјаја и тишине, који је „уједињен заједничким насловом и повезан тематским и жанровским обиљежјима“ (Ужаревић 1991: 142-159). 
вишег реда, проистичу из свеприсутних текстовних спона: везујућих иниеениионалних чинилаца.

Занимљиво је да је Борислав Михајловић, састављач антологије Срйски йјесници између gва райа из 1956. године, о песнику Андрићу, објављујући четири песме „Шта сањам и шта ми се догађа“ навео следеће: „Мисао и атмосфера. Порука себи више него порука свету“. У овој акутној везаности и прикопчаности за простор сопства као за јеgиносй у ком свет може присуствовати у двогубости сна $u$ догађаја,

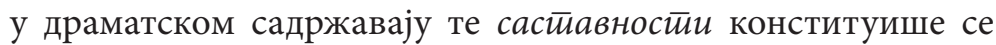
лирски глас без дистанце према свету, јер свет постаје његов (са)садржај. Одсуство дистанце у односу лирско ја-свет препознатљива је одлика лирике, по мишљењу Емила Штајгера, али уклоњено одстојање андрићевске песме не потиче само из фундаменталних својстава лирскоі̄ модуса, већ из опредељења $3 а$ говор и песничко мишљење сопства. Међутим, пре него проговоримо о питањима херменеутике лирског субјекта и естетичко-поетичким особеностима форме, тј. о садржају и интенционалностима слоја представљених предмета, шематизованих изгледа и метафизичких квалитета, који та питања установљују, одговоримо на елементарно питање тумачење поезије. Наиме, још је Фридрих Шлегел у Разі̄овору о йоезији говорио о двема врстама представе уметничког дела: сйољашюој и унуйрашюој, где унутрашња постаје потпуно јасна сама за себе захваљујући спољашњој. Ова спољашња представа као питање песничког језика, модуса лирског говора и његове манифестације кроз одређену песничку форму у теорији Романа Ингардена везује се за тзв. слој звучања:

Одређени језичко-звучни матиеријал некоі книжевноі gела у неком језику нужан је и за йостиојане дела у чийавом юеіовом ориіиналном, естиетички вредносном вияу. [...]

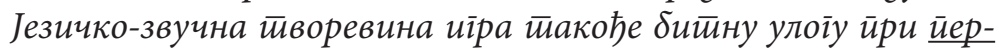

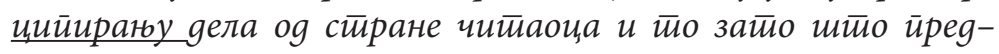

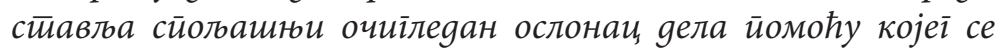

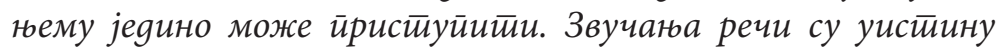

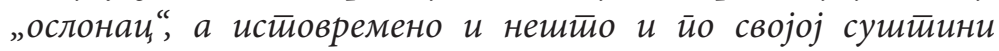




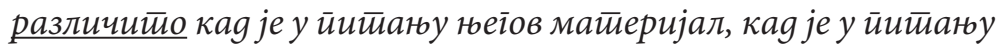
све оно шито се осим йоіа налази у gелу. Ова звучаға йри

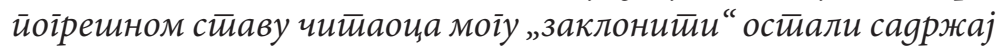

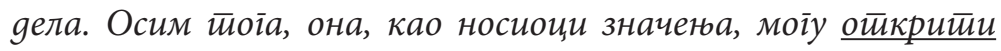

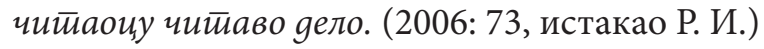

Визуелни лик Андрићевог циклуса сачињен је од строфоида, уз коришћење лирског говора и лирског казивања у слобоgном сиииху. ${ }^{9}$ Како форма слободног стиха подразумева неприсуство изометрије и изострофичности, клаузуле нису у облику риме, међу њима нема каузалности ни нарочите законитости распоређивања. Дакле, ритам и сонорност класичне метричке структуре нису обликовали језичко-звучни материјал ове Андрићеве песме. Перманенто лирско у њој је ритам, ритам који је неодвојив од песничке визије, ингарденовски казано, кроз ритам се открива слој шематизованих апеката: идеје, метафизичке и естетичке квалитете. Размотримо ритмичку структуру уводне песме:

Будим се врео. Нека зора обећана.

И како ми је остало од старих:

Благодарим за сан и хлеб и секунд и помисоิ

Угледах торањ, иза грања, што молитве прима;

Од стабла к стаблу венци разапети

Лозова лишћа. (Свечаност се слути

И радује тајно.) А сјај преко неба

И земље, румен сјај што расте

У очи и мисли, путује, шири се,

Витла, стреми, ако сте гледали,

Ко̂ силна магла планинских понора,

Тек бескрајно већи.

И гле, то што снивах, сиромах Босанац и дете,

Да се прокљује једном модра опна изнад главе

И да се - види? Чује? -, сад бива:

Смисао. Сталност. Без љаге промене, страха.

9 Иво Андрић је са првим песмама које је објавио у Хрвайској млаgој лирици (Загреб, 1914) био препознат као песник слободног стиха, поред Камова. 
Добра лепота. Вест из далека.

Дело које се сања. Оно што човек

Једном другом не може никад да каже.

Ал’ то само узалуд помишља: ни стаза ни имена.

Васион престол од немога злата.

Нови се сјајеви рађају и расту.

Ни стаза ни имена!

Све то

Још понајвише наличи таласу, и древну ритму, и коначно, тишини. (1922: 78)

Особена сонорност наведених стихова потиче, на једној страни, из интензивног присуства фигуре йолисинgетион (везник $u$ ), који се на моменте пресеца асинgетионом, а на другој, из ритмичких пауза проистеклих из опкорачења (између стихова), парантезе, и елипсе, фигуре која је ослоњена на нанизане беспредикативне реченице. Ритмичка интонацијска пауза, које истиче значењске јединице, дајући посебну мелодичност тексту као оралном материјалу спроведена је и у обликовању краја песме. Разглобљеност последњег стиха, која уз присуство анаколута спушта идејно-семантичко жариште на исказ „коначно, тишини“ открива моменте шематизованих аспеката света дела, сенчећи његов $\bar{u} р а н-$ сиенgирајући садржај. Наиме, присуство полисиндетона

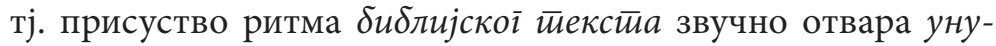
$\bar{u}$ рашъьсти осталих слојева, алудирајући на атмосферу сакралної. Међутим, активирани библијски подтекст изручен је динамици прекодирања, тј. уписивања нових значења.

Наиме, када промотримо прву строфу уводне песме, тј. уочимо (и чујемо) њен језички материјал и мелодију, који садржи „манифестујуће квалитете“, јер „ствара трајне асоцијације с различитим врстама изілеgа“" (Ингарден 2006: 245), уочавамо предметни слој са израженом релиїијском симболиком: „торањ, што молитве прима“, „разапети венци лозова лишћа“, „румен сјај“. Лирска визија есхайо момента, попут оне која обликује Хелдерлинов „Празник Мира“, не везује се, међутим, за одређену представу хришћанства. Напротив, она 
је од почетка разуђена неодређеношћу: „Нека зора обећана.“

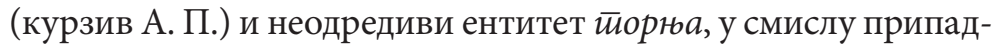
ности (минаре или хришћански звоник?) одмичу слој предметности од јасне фиксираности за хришћански или исламски контекст, тј. слој шематизованих аспеката / изгледи који припадају предметима, њихова потенционалност подешана је да се конкретизује као неодредиво место значења. Неопипљиво поље означеноі „нека зора обећана“ происходи из означииеељске позиције лирског субјекта, која затамњује порекло обећаног, смештајући га у простор сойсйва:

И іле, йо шимо снивах, сиромах Босанаи, и gетеие, Да се йроктује јеgном моgра ойна изнаg ілаве И ga ce - вugu? Чyje? -, cag ठuвa:

Смисао. Сйалносй. Без тайе ӥромене, сиираха. Дољра лейойа. Вести из далека. Дело које се сана. Оно шито човек цеgном gруїом не може никаg gа каже (истакла А. П.)

Градационо поређане елиптичне реченице износе садржај сневаног: разрешење онтолошког конфликта, остварен егзодус човека испод модрине свода. Међутим, овде не говоримо само о једноставном низу исказа, обликованих реторским фигурама елипсе и градације, већ нам је $\bar{u} y н u н а$

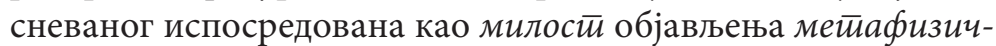
ких квалитетйа песме, а тај излаз из нескривености, према Ингардену, условљен је укупношћу структуре књижевног уметничког дела:

Дело књижевне уметиностии свој врхунаи gостине у

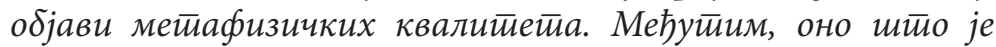
инстичнски уметиничко заснива на начину тьхової објављи-

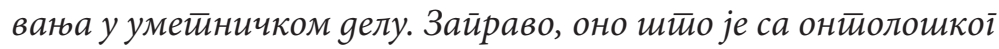

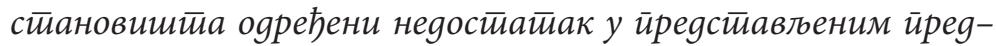
мейима, а йо је gа они немају реални неіо само инитениионални хеиеерономно-еїзисиенцијални начин йостиојать и gа у свом саяржају имају хабитиус сииварносии и оређене врстие, омоіућава им објављиване метиабизичких квалитетета на

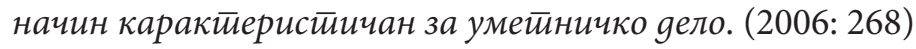




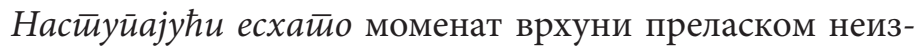
речја у реч - есхатолошко време јесте време ойвореностии у (раз)говору, где оно никад неречено присуствује. Но, друга строфа опонира садржају прве, јер „то се само узалуд помишља“, те тишина на крају песме наступа као axis mundi, вертикална оса светова кроз коју се додирују земаљски, сав у кретању и вечни, трајни свет непостојања и непокрета: васион сав у немом злайу. Румени сјај есхато тренутка претака се у сјај световања света: Нови се сјајеви рађају

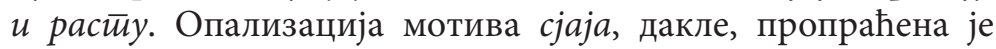
ширењем опсега његових значењских јединица, одакле се шири и слој предметности света дела и слој шематизованих изгледа. Истом поступку, постепене ойализације, развијањем вишезначја кроз циклус подвргнут је и мотив йишине. Наиме, у последњој, десетој песми лирски субјекат изналази $\hbar y \bar{u} а$ юе као „неизрециву снагу“, као сопствену прагматику у самоочувању испод неба које је гробница:

Ал' веће сластии не йознаgох ов мисли:

Да је небо, шиио сја наg нама као обећане,

само іробниия;

а достиојанстиво једино

и јеgина молитива йрава:

оборене очи и устй која ћуйе.

Моја ме мисао као сјај невиялив воgи

Док ияем кроз ноћ и маіллу. (1931: 102, истакла А. П.)

Стапање бинарних опозициија горе: доле у песничку слику неба-гробнице, празни садржаје представе неба које сија као обећање, чиме се религијске конотације потискују на рубна места дискурса. Неодређен квалитет обећане зоре из уводне песме, дакле, разрешава се у семеми / значењској јединици везника као, док се тичшина и сјај васиона поунутрашњују, дајући завршну нијансу метафизичких значења песме. Када упоредимо слој предметности и шематизованих аспеката прве и последње песме, видно је померање религијских мотива ка стиарағу о себи у духу стоичке праксе, 
померање које се одиграва кроз читав циклус. Недокучивост неизречја: оноїа шйо човек јеgном друі̄ом не може gа каже и драматска структура бивања у саставности догађаја $u$ снова,

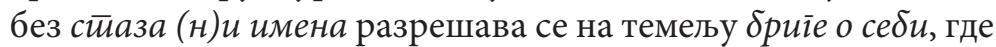
поље сопства анулира појам gуше. Сужавање његових шематизованих аспеката протеже се дуж циклуса, творећи простор за модернистичко искуство субјективитета.

Пре него прокоментаришемо завршна запажања о садржају лирског циклуса, задржимо се, накратко, на стиху $И$ іле, $\bar{и} о ~ и \overline{и о ~ с н и в а х, ~ с и р о м а х ~ Б о с а н а и, ~ и ~ g е и ̆ е ~ и з ~ п р в е ~ с т р о ф е ~}$ уводне песме. Како је ентитет сиромах Босанац (најмање) двоструко одређен: социјалним (класним) статусом и геополитички/национално, поставља се питање може ли се допрети до слоја шематизованих изгледа која га опредмећују, ако примењујемо све условности примењивање феноменолошке методе које је поставио Ингарден. Споменути садржај би могао бити камен спотицања за феноменолошки приступ. Откуд Босанаи, у сну лирског субјекта и зашто? Излаз из модрине која зайвара и учешће у gоброј лейойи прикопчан је за представу Босанца и детета која је творена само на нивоу именовања. Међутим, премда сведена, она се у контексту стихова, у окретању садржаја који се за њих сања као

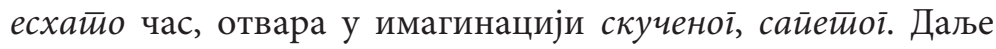
тумачење би изискивало примену іеокулйуралне имаїинаицје и укључивање у потоње токове српске поезије како би се разазнала начела и условности лирског ойросӣоравана простора Босне. ${ }^{10}$

Ингарден се, са друге стране, не бави облицима простора

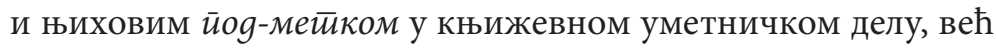
настоји да у битном смислу одвоји онтолошки статус реалног

10 Уколико бисмо песничке ентитете „сиромах Босанац“ посматрали у социјалном, политичком и историјском кључу, дакле, мимо „метафизичке осене“, указала би се једна нит унутар андрићевског стваралаштва - заинтересованост за идеју друштвеног напретка и просперитета. Парадигматична је приповетка Елекӣробих из 1948. године у Бразgа, год. 1, бр. 1 (15. Јануар 1948), 5-8, потом у издању из 1952. год. Pod grabićem: pripovetke o životu bosanskog sela, Sarajevo: seljačka knjiga; Novi Bečej: Proleter (извор: Библиоірафија Иве Анgрића). Међутим, у Новим йрийовейкама (1948) поменутог дела нема. 
простора од простора у литерарном остварењу. Наиме, према Ингарденовој поставци, сви садржаји представљени у делу, па и они просторно-временски, „не припадају стварно реалним предметима, него чисто интенционалним који су једино по свом садржају quasi-реални“, те се о њима може говорити у оквиру йулсирајућеi начина доживљавања, јер „читалац не може доживети читав continuum изгледа са подједнаком живошћу и оштрином.“ (2006: 248, курзив Р. И.) Дакле, читалац конкретиизаиијом разбија continuum мноштва предмета и њихове предоџбене изгледе. Ингарден се овде осврће на драмско дело које постављањем на позорницу реализује неке слојеве у извесној мери (2006: 249). Читања су, дакле, „једна од његових могућих варијанти“, док је књижевно дело целина, која се не може једначити са укупношћу појединачних читања, те нам се акт читања обзнањује у проблематичној ситуираности између (полифоније) целине и активирања појединачних њених слојева, изгледа. Колико је разумевање слојева склиско подручје, показује тумачење Петра Џаџића. Наиме, овај књижевни критичар и познавалац Андрићевог дела у стиховима треће песме: То ми се ойей јављьаш $\bar{u} u, y$ звуку, / И ово се чуgо неће објавитии никаg, / Неі̄о ће увекћуйке

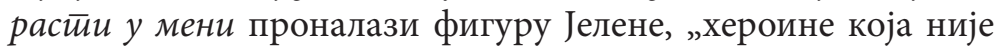
облик и тело него флуид и звук“ (1981: 266-267). Међутим, његово разумевање редукује вишезначје, смањујући опсег ойалностии. Промотримо садржај песме:

Иза ӥреgірађа, gалеко,

На крају шума

Које бојажљиво круже око іраgа,

На ситрмој и нейловној равни,

Без имена и тейойе,

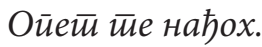

Заробльен у једва чујном звуку

Који ирролази осамљьен овим крајем

To си $\bar{u} u$,

Смислу и забораву,

Свих йуйева и снова.

Без среће. Без речи. Саме звезде слазе 
У скуй засйалу йросјаку.

То ми се ойей јављьаш йи, у звуку,

И ово се чуgо неће објавити никаg,

Неіо ће увек ћутике растии у мени,

Докме не йонесе

Као најснажнија крила. (истакла А. П.)

Значењски слој стихова Зароблен у јеgва чујном звуку не раскриљује ентитет заробљеног̄, као што ни идентификација То си йи. / Смислу и забораву. / Свих йуйева и снова. не даје основа за тврдњу да је то Јелена, жена које нема или Бог. Напротив, нема ниједног лексичког облика који би сигнализирао обликовање одређене фигуре. Свеобухватни садржај смисла и заборава јесте неименльи, јер изражена метафизичка функција шематизованих аспеката која уцеловљује циклус, не допушта конкретизовање. Растуће чуgо y лирском субјекту остаје садржај сопства, његово зреюе у тишини, бивање у састварности сневаног $u$ догађајног, које, напослетку, задобија лик светиле мисли о дигнитету човековог бића. Преточено у феноменолошки дискурс, неименљиво остаје неименовано у читању, јер је место неоgређеностии које се по својој интенционалности ни у једној конкретизацији не може доћи до довршења значења (Ингарден 2006: 308).

Чудо које остаје чудо, иако се никад неће објавити и у пулсирајућој измаглици (потенционалних) значења у лирском простору „Шта сањам и шта ми се догађа“ наставља се снагом жеље, која се унутар искуства субјективитета распрскава у еротско-сексуалне садржаје (у другој песми), чезнутљиве пределе даљина (осма песма), али и на метафизичке квалитете у седмој песми:

На йуђем мору. Не иррайе мене

Сенке gоброі воћюака

Ни вишеіраяска стиаза, увек йужна

Блеgе блаїостови.

Тону gарови у gанима и мору;

Гину ожитии рана и миловаға

За увек! 
А изная мене и неба и мора

Цедино име, иить и знак и снаїа:

Жеђ моја бескрајна времена и светиа. (истакла А. П.)

Растресита именичка синтагма која сачињава значењску јединицу последњег стиха утростручује однос припадности. Жеђ лирског субјекта поистовећена је са жеђу времена и света - она је истовремено интимно лична и надлична, по нечему универзална у својој интенцији. Прегнантан садржај потиче из ширеюа света предметности дела и шематизованих аспеката, којим се модернистичко искуство субјективитета пресеца онтолошким питањима, излази из (само) задатог поља сопствености и отвара се ка светоодносу и темпоралности.

Мотив жеље/жеђи попут мотива чуда губи место у координатном ситему, јер хоризонт на коме се његова значења уписују и остварују, у битном смислу, јесте естеитички. Наиме, наведене метафизичке особености текстовности лирског циклуса, сав садржај из домена сазнања преточен је у облик који одржава и омогућује њихово исијање. Лирски ирремер као мелодија, ритам и темпо, на једној страни, и као иесничко мишљење, на другој, чини да сневано $и$ догађајно Андрићеве десетоделне песме надрасте оно „ништа“ у чуgo књижевноуметничког дела. ${ }^{11}$

11 „Књижевно дело је право чудо. Постоји, живи, утиче на нас изузетно обогаћује наш живот, дарује нам сате одушевљења и омогућава да се спустимо у непрегледне дубине наше егзистенције, а заправо је само егзистенцијално-хетерономна творевина, која у смислу егзистенцијалне аутономије готово да је ништа. Ако хоћемо теоријски да сагледамо, одмах нам се појављује сложеност и вишезначност које се једва могу сагледати, јављају се пред нама у естетичком доживљају као целина кроз коју ова компликована грађа једва да светлуца. Она поседује хетерономну егзистенцију - како се чини - сасвим пасивну, која беспомоћно подноси све наше операције, а ипак захваљујући својим конкретизацијама изазива у нашем животу дубоке промене, шири га, издиже изнад сивила свакодневног битисања, даје му божански одсјај, „ништа“, а истовремено је само по себи чудесан свет, мада настаје нашом вољом и нашом вољом йосӣоји.“ (Ингарден 2006: 332, истакла А. П.) 


\section{Закључна разматрања}

Тумачећи Андрићев циклус песама „Шта сањам и шта ми се догађа“, настојали смо указати на елементе циклизације, посветивши се првој и последњој песми. Јер, у овим двема песмама се заправо зачиње и сустиче укупност уметничких и естетичких особина са еманациојм метафизичке вертикале. Настојали смо да на практичном примеру, умилостивимо демона теорије, спуштајући уопштен фон феноменолошке методе ${ }^{12}$ у пуно, конкретно присуство књижевноуметничког дела. Читање из угла ингарденовских поставки имало је два задатка. Први, да отвори видик на Андрићеву поезију, која је у осени чеоне стране пишчевог опуса - прозе, ${ }^{13}$ а други да критички промотри оствариве домене феноменолошког приступа у интерпретацији. Упознајући и примењујући садржај Ингарденове студије $O$ књижевном gелу, дошли смо пак до сазнања одређених апоретичних момената феноменолошке методе. Наиме, Ингарден је своје претпоставке извео из Хусерлове филозофије, али полемишући са њом, битно удаљио од тла филозофског мишљења као таквог, стога Миливој Солар бележи:

12 Зоран Константиновић, пишући о феноменолошкој методи унутар научног приступа књижевности, наглашава да његова студија Феноменолошки йрисӣуū књижевном gелу има примарни задатак да међупростор између филозофије и науке о књижевности испуни методолошким апаратом који би одговарао епистемолошким захтевима науке о књижевности, приближујући општу филозофску проблематику конкретном књижевном делу. Аутор наводи мислиоце који о уметничком делу говоре на уопштеном филозофском фону, међу којима се спомиње и Ингарден (1969: 11-12).

13 Андрић је лирске форме сматрао мање уметнички успелим од прозних остварења, што се да̂ видети из његових изјава и писама: „Ја сам есеје, као и стихове, писао у предасима, одмарајући се од тешког рада на приповеткама и романима. Моје је право да мислим да ту нисам постигао оно што ми је пошло за руком у другим делима. Увек ми се чини да сам у песмама само вежбао за напоран рад који ме је чекао у зрелим годинама“ (Јандрић 1977: 130);

„Изгледа да је то једна неминовност: лирски део стварања једног писца неопходан је у његовом развоју, разумљив и присан савременицима, али од подређеног значаја према целом његовом животном делу“ (из писма Милану Марковићу, 3.4.1938; 1981: 262). 


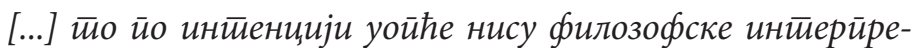
йације книжевних яјела, нитии иоосреgно нитии нейосреgно, неїо су метиодички сиироїе анализе йојавливана кюижевностии у искустиву, односно сйознаје књиневних gјела, како се и зове јеgно Инаїрgеново яјело („О сазнавању књижевноі умей-

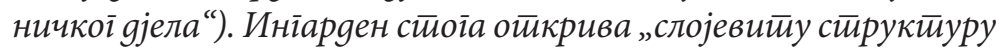
кюижевноі gјела“" изірађујући нешито шито има каракиерер формалне анализе констиитуирана искустиава книжевноі gјела, ирри чему се алеїореза може замислитии јеgино као ияеал gо којеі ће се, можgа, јеgном gоћи у йроїресу знанстивене сииознаје. Каgа йак Инїарgен сировоgи [...] инйеритретиацију књижевноі gјела,

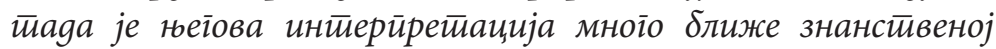

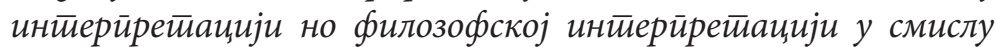
алеїорезе, јеgино шито знаности коју он жели изіраяити иойире

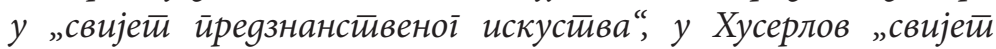

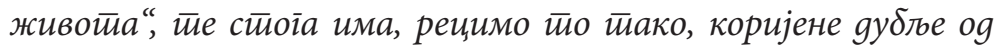
коријена емитиријске знаностии. (1985: 195)

Одговарајући на питање како се књижевно gелу у све-

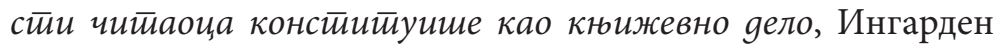
je, дакле, обликовао методолошку, приступну апаратуру. У обухватом прегледу савремених теорија у науци о књижевности Книжевне тееорие XX века Ане Бужињске и Михала Павела Марковског феноменологији је посвећено друго поглавље (в. 2009: 89-120). Аутори са правом запажају да је феноменологија данас изгубила своју динамику:

Иако несумниво ӣрийаgају канону кюижевнотетеоријске

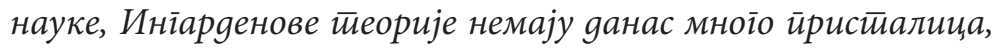

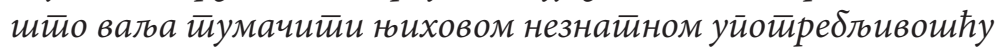

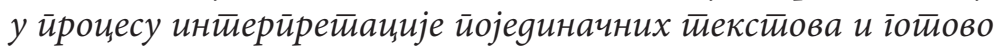

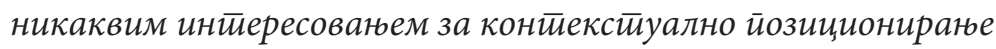
къижевностии. (2009: 112)

Међутим, иако апстрактна и уопштена, феноменолошка мисао у конкретној примени отвара, уколико се не узме у дословном емпиријском/формалном оквиру, йрансцеguрајућу функцију језика унутар структуре 
књижевноуметничког дела. Jер, вишеслојност књижевног дела и ойализација, у крајњој консеквенци, јесу откривање језика у нейосреgном йрисусииву (видети Солар 1985: 126). Она се, дакле, може практиковати у дијалошком простору између науке о књижевности и филозофије књижевности, у динамици размицања епистемолошких граница једне и друге науке. Стога, њен карактер неgовршеносиии нам оставља плодно тле за даље промишљање идентитета књижевноуметничког дела и његових садржаја.

\section{Извори и литература:}

Андрић, Иво. „Шта сањам и шта ми се догађа“. Мисао, X, 1 (1922): 1248-1249. Штампано.

Андрић, Иво. „Шта сањам и шта ми се догађа“. Мисао, XIII, 3 (1923): 1398-1399. Штампано.

Андрић, Иво. „Шта сањам и шта ми се догађа“. Преїлеg, VII, 92 (1931): 101-102. Штампано.

Андрић, Иво. Ex Ponto, Немири, Лирика, Беоіраg: Просвета, 1981. Штампано.

Bužinjska, Ana i Mihal Pavel Markovski. Književne teorije XX veka. Prev. Ivana Đokić-Saunderson. Beograd: Službeni glasnik, 2009. Štampano.

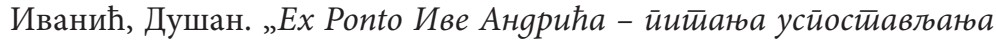
основноі йекстиа“. Книжевна истиорија, XII, 47 (1980): 377-389. Ingarden, Roman. O književnom delu. Prev. Radoslav Đokić. Beograd: Foto Futura, 2006. Štampano.

Јандрић, Љубо. Са Ивом Анgрићем. Београд: СКЗ, 1977. Штампано. Константиновић, Зоран. Феноменолошки ӣрисииуй книжевном gелу. Просвета: Београд, 1969. Штампано.

Liotar, Žan-Fransoa. Fenomenologija. Prev. Mirjana Zdravković. Beograd: BIGZ, 1980. Štampano.

Sartr, Žan Pol. O književnosti i piscima. Prev. F. Filipović. Beograd: Kultura, 1962. Štampano.

Solar, Milivoj. Filozofija književnosti. Zagreb: SNL, 1985. Štampano.

Стерјопулу Апостолос, Елена. Поейика тирскоі ицклуса на матиеријалу руске йоезије с краја XIX и йочейком XX века. Прев. Добрило Аранитовић. Београд: Народна књига, 2003. Штампано. 
Стојановић, Драган. Феноменолоіија и вищезначносй књижевної gела: Иніарgенова йеорија ойализащије. Београд: Просвета, 1976. Штампано.

Užarević, Josip. „Kompozicijsko značenje smrti“. Kompozicija lirske pjesme. Zagreb: Zavod za znanost o književnosti filozofskog fakulteta u Zagrebu, 1991. Štampano.

\title{
Aleksandra Paunović
}

\author{
IN THE LYRICAL MEASURE OF DREAM \\ AND REALITY: „WHAT I DREAM OF AND WHAT \\ HAPPENS TO ME" BY IVO ANDRIĆ ${ }^{14}$
}

The paper considers literary-theoretical, literary-critical and cognitive-interpretive possibilities and the scope of the phenomenological method in understanding Andrićs ten-part poem, entitled "What I Dream of and What Happens to Me". In this paper, we shall interpret the text pertaining to Andrićs lyrical cycle by means of Ingarden's methodology and theoretical postulates provided by the studies On Literary Work and On Knowledge of Literary Art, accompanied by the echoes of this methodology, its application and limitations within the Serbian literary critical thought (provided by Zoran Konstantinović, Dragan Stojanović).

Key Words: Andrić, Ingarden, Phenomenological Method, Lyrics, Philosophy of Literature, Literary Theory, Layer, Opalization.

14 The text of this paper was created as a result of participation in the project The Shift of Poetic Paradigms in the Serbian Literature of the Twentieth Century: The National and European Context (project number: 178016) of the Institute for Literature and Arts (Belgrade), which was funded by the Ministry of Education, Science and Technological Development of the Republic of Serbia. 